DOI: https://doi.org/10.24867/13GI08Lugonja

\title{
ANALIZA POTROŠAČKIH PREFERENCIJA U OFLAJN I ONLAJN KUPOVINI ŠOPING PROIZVODA
}

\section{THE ANALYSIS OF CUSTOMER PREFERENCES IN OFFLINE AND ONLINE PURCHASE OF SHOPPING PRODUCT}

\author{
Kristina Lugonja, Fakultet tehničkih nauka, Novi Sad
}

\begin{abstract}
Oblast - INŽENJERSKI MENADŽMENT
Kratak sadržaj - U radu se razmatra područje ponašanja potrošača, faktora koji utiču na njihovo ponašanje, kao $i$ odlučivanje potrošača o kupovini proizvoda uz poređenje oflajn i onlajn navika potrošača. Istraživanje stavova, mišljenja i navika potrošača u kupovini šoping proizvoda (odeće) ukazuje na davanje prednosti oflajn kupovini, u odnosu na onlajn kupovinu.
\end{abstract}

Ključne reči: Analiza, ponašanje potrošača, proizvodi, oflajn i onlajn kupovina

Abstract - The paper discusses the area of consumer behavior, factors that influence their behavior, as well as consumer decision-making on the purchase of products with a comparison of offline and online consumer habits. Researching the attitudes, opinions and habits of consumers in the purchase of shopping products (clothing) indicates the preference for offline shopping, over online shopping.

Keywords: Analysis, consumer behavior, products, offline and online shopping

\section{UVOD}

Posebni (šoping) proizvodi su proizvodi za koje potrošači smatraju da je vredno pažnje ulaganje napora za pažljivo upoređivanje i ispitivanje kvaliteta, cene i stila konkurentskih proizvoda. Obično kupci razgledaju ove proizvode $\mathrm{u}$ vise prodavnica pre kupovine. $\mathrm{U}$ odnosu na obične proizvode, šoping proizvodi su mnogo skuplji i kupuju se ređe [1]. Takođe, za ove proizvode se odluka o kupovini donosi mnogo teže i uz detaljnije ispitivanje kriterijuma. Kupovina ovih dobara predstavlja zadovoljstvo.

Područje ponašanja potrošača je veoma široko i kompleksno. Proučavanjem njihovog ponašanja istražuje se kako pojedinci donose odluke o potrošnji svog novca, kao i ulaganja vremena i energije na kupovinu proizvoda i usluga. Ponašanje potrošača je neprekidan i sveobuhvatan proces koji, pod uticajem različitih faktora, počinje pre samog početka procesa kupovine i odvija se korišćenjem proizvoda i usluga, i posle kupovine [2]. U današnje vreme potrošači su sve svesniji mogućnosti i različitosti proizvoda, pa ih je sve teže pridobiti.

\section{NAPOMENA:}

Ovaj rad proistekao je iz master rada čiji mentor je bila doc. dr Jelena Spajić.
Zbog toga je jedna od osnovnih funkcija marketinga stalno praćenje $\mathrm{i}$ istraživanje potreba i želja potrošača i potencijalnih potrošača i načina na koji oni donose odluke u kupovini. Zadovoljni potrošači će kupovati proizvod i prenositi drugima pozitivne informacije o proizvodu $i$ samoj kompaniji.

Postoje raznovrsni faktori koji utiču na potrošače i njihovu odluku o kupovini. Osnovne grupe faktora predstavljaju ekonomski, sociološki i psihološki faktori. U ekonomske faktore spadaju opšti ekonomski uslovi na tržištu i u okruženju, prihodi i rashodi, sklonost potrošnji ili štednji, raspoloživi i diskrecioni dohodak i cenovni i necenovni faktori. Potrošač je jedno socijalno biće, pa samim tim na njega djeluju kultura, subkultura, društvo i slojevi, društvene grupe i porodica. Za razliku od ekonomskih i socioloških faktora ponašanja potrošača, koja ne uzimaju u obzir lični, pojedinačni - ljudski faktor, psihološko objašnjenje istražuje interne procese koji se odigravaju u ličnosti, a od kojih zavisi kako će ta spoljna delovanja osoba primiti, shvatiti i na kraju reagovati. Psihološki faktori koji utiču na ponašanje potrošača su motivacija, percepcija, učenje i uverenja i stavovi [3].

Pored ovih faktora, na ponašanje potrošača deluju i specifičnosti Interneta i WOM (Word of Mouth) komunikacije. Društveni mediji u velikoj meri utiču na potrošače u smislu razmene mišljenja i stavova u vezi sa proizvodima i njihovim uslugama [4]. Takođe, influenseri su osobe koje imaju uticaj na potrošače i kojima oni veruju. Oni su korisnici društvenih mreža koji imaju široku publiku i koji su u stanju da svojim objavama utiču na ljude koji ih prate i na njihove odluke.

Digitalni marketing i njegovi kanali snažno utiču na potrošače u smislu oglašavanja na internetu, društvenim platformama i kroz niz drugih mogućnosti [5]. On se razvija konstantno i veoma brzo. Pred potrošačima je niz ponuda, reklama i predstavljanja proizvoda, a njihove glavne odluke su vezane za to šta kupiti, u kojoj količini, u koje vreme, na kom mestu i kako kupiti, odnosno način plaćanja.

Odlučivanje potrošača o kupovini marketing stručnjaci smatraju jednim od najvažnijih procesa u marketingu jer se cela marketinška strategija kompanije prilagođava kupcima. Kompanija je uspešna samo kada je kupac svestan potrebe za proizvodom kompanije, smatra proizvod te kompanije najboljim i diferencira ga u odnosu na druge proizvode. Odlučivanje potrošača se manifestuje kroz svesnost potrebe, traženje informacija, procenu alternativa, kupovinu i ocenu nakon kupovine [6]. 


\section{POREĐENJE NAVIKA OFLAJN I ONLAJN POTROŠAČA}

Navike potrošača $u$ kupovini su se $u$ velikoj meri promenile sa pojavom Interneta. Pored tradicionalnih, javljaju se i elektronski prodajni kanali. Nude se razne mogućnosti za kupce, od dugih sati hodanja po tržnim centrima do kupovine putem pametnih telefona.Mnogi faktori utiču na izbor prodajnog kanala, među kojima su najvažniji faktori u pogledu karakteristika potrošača i vrste proizvoda.

Kod onlajn kupovine kupci imaju skoro neograničen izbor proizvoda, mogućnost da lako porede proizvode, cene i komentare ostalih kupaca, kao i da obave kupovinu bilo kada, na bilo kom mestu, po nižim cenama i nižim troškovima kupovine. U odnosu na tradicionalnu, onlajn kupovinu karakteriše nesigurnost, anonimnost, nedostatak kontrole i oportunizam prema kupcima [7]. Od kupaca se zahteva da dele lične i finansijske informacije, da veruju da će im se isporučiti proizvod koji je opisan, kao i da veruju u sigurnost i tačnost isporuke. Poverenje je jedan od ključnih razloga zbog kojih se potrošači ne odlučuju na onlajn kupovinu. Da bi se odlučili za istu, potrebno je da poseduju određeni nivo poverenja.

Oflajn kupovina se odnosi na kupovinu proizvoda i usluga na licu mesta, odnosno u prodavnicama. Kupci mogu neposredno da se informišu o proizvodima, njegovim karakteristikama, načinima upotrebe i sl. Mnogi potrošači obavljaju kupovinu zbog razonode i osećaja ispunjenosti kada pronađu predmet kojim zadovoljavaju svoju potrebu ili želju. Kupci i dalje preferiraju da proizvod osete, dodirnu, probaju na klasičan način[8]. Razgledanje prodavnica, druženje, probanje proizvoda, razgovor sa prodavcima, izgled ambijenta, muzika, celokupan doživljaj kupovine predstavljaju neprocenivu vrednost za veliki broj potrošača.

Kao ključne razlike $u$ ponašanju onlajn potrošača $u$ odnosu na oflajn potrošače u kupovini mogu se izdvojiti [9]:

1. Ne postoji ograničenje u smislu lokacije: Onlajn kupac može da kupuje praktično sa bilo kog mesta, dok oflajn kupac će češće odabrati prodavnicu na osnovu svoje geografske lokacije, tj. u blizini kuće ili posla. Samim tim, onlajn prodaja omogućava kompanijama da dosegnu veću bazu kupaca izvan grada ili čak zemlje, što dovodi do povećanja prodaje.

2. Pogodnost za kupca: Onlajn kupci mogu da kupuju u bilo kom trenutku, bez vremenskih ograničenja, dok oflajn kupci mogu da posećuju prodavnice samo u toku radnog vremena kada su radnje otvorene. To znači da oflajn poslovanje ne prestaje. Pored toga, onlajn kupac ima mogućnost „samoplaćanja“, sa različitim načinima plaćanja kao što su pouzeće, debitne ili kreditne kartice i sl. Takođe, pošto se isporuka proizvoda vrši na adresi po izboru kupca, oni čak ne moraju da nose i teške kese/torbe.

3. Poznavanje proizvoda pre nego što ga kupe: Veoma često se dešava da kupci uđu u prodavnice i nisu sigurni šta žele da kupe. Pregledavaju više proizvoda, pokazuju interesovanje i postavljaju razna pitanja, a možda ih ne kupe. To dovodi do dodatnih napora $u$ procesu ubeđivanja kupca da obavi kupovinu i ponovnog preuređivanja izgleda prodavnice. Za razliku od nih, većina onlajn kupaca zna šta želi da kupi. Kada sumnjaju, onlajn kupci mogu pročitati detaljne opise proizvoda i uporediti različite ponuđene proizvode $\mathrm{i}$ izvršiti kupovinu bez pomoći prodavača. To dovodi do minimiziranja troškova osoblja i olakšava postupak kupovine kupcu.

4. Izgled prodavnice nije faktor koji doprinosi kupovini: Za onlajn kupca način na koji izgleda prodanica nije važan sve dok je proizvod u koji ulažu dobrog kvaliteta. To pomaže kompanijama u smanjenju troškova ukrašavanja i koncentracije na kvalitet proizvoda. Na oflajn kupca može uticati izgled prodavnice, čak pre nego što je video proizvod.

\section{ISTRAŽIVAČKI DEO RADA}

\subsection{Predmet, cilj i uzorak istraživanja}

Cilj istraživanja je dobijanje podataka o ponašanju potrošača i njihovim preferencijama $u$ oflajn i onlajn kupovini, odnosno analiza i objašnjenje ponašanja potrošača pri kupovini šoping proizvoda (odeće). Potrošači se različito ponašaju u kupovini i na njih deluju različiti faktori. Istraživanjem se nastoje otkriti specifičnosti ponašanja potrošača.

Predmet istraživanja predstavljaju specifične navike i stavovi potrošača pri izboru odeće u oflajn i onlajn prodavnicama. Izazovi se kriju u stalnom praćenju promena vezanih za potrebe, želje i navike potrošača pri donošenju odluka o kupovini i, na osnovu toga, prepoznavanju šansi za unapređenje.

$\mathrm{U}$ ispitivanju je učestvovalo 120 ispitanika, oba pola i različite starosne dobi. Dominiraju ispitanici ženskog pola (65,8\% ispitanika) i starosne dobi od 15 do 25 godina.

\subsection{Metod $i$ instrument istraživanja}

Empirijsko istraživanje se sprovedeno metodom onlajn upitnika kao glavnim instrumentom istraživanja. Ispitanici su bili anketirani putem onlajn upitnika (google forms), u periodu od 13.10.2020. do 23.10.2020. godine.

Ispitanicima je postavljeno ukupno dvadeset pet pitanja, od kojih su tri pitanja bila u vezi socio-demografskih karakteristika, a ostala dvadeset dva pitanja su bila vezana za stavove, mišljenja i navike ispitanika u vezi sa ponašanjem i donošenjem odluke o kupovini odeće.

\subsection{Rezultati istraživanja}

Radi preciznije analize i objašnjenja, izabran je konkretan poseban (šoping) proizvod - odeća, i na osnovu prikupljenih informacija o ponašanju potrošača pri kupovini ovih proizvoda, izvedeni su zaključci.

Rezultati istraživanja pokazuju da veći deo ispitanika čine pripadnici ženskog pola i mlađe populacije, s obzirom da mlađi predstavljaju ciljnu grupu, a anketa je sprovedena na internetu gde je najveća koncentracija mladih. Prema stepenu obrazovanja dominiraju ispitanici koji su fakultetski obrazovani, srednjoškolci i masterovci.

Kao najčešći vidovi informisanja potrošača o samim prodavnicama i odeći koju nude, informisanje u fizičkim 
prodavnicama i putem internet pretrage predstavljaju najpopularnije vidove informisanja, zatim preporuke, odnosno mišljenja i iskustva porodice i prijatelja, dok su reklame i recenzije za većinu ispitanika predstavljene kao najređi vidovi dolaska do potrebnih informacija. Po pitanju izbora prodavnice u kojoj će se obaviti kupovina, preko polovine ispitanika kupuje odeću isključivo u fizičkim (oflajn) prodavnicama, zatim kombinovano u oflajn/onlajn prodavnicama, dok je kupovina isključivo u onlajn prodavnicama najmanje označena.

Više od polovine ispitanika preferira prikupljanje informacija o odeći putem interneta, a kupovinu u fizičkim prodavnicama, odnosno 55,8\% ispitanika. Zatim, dominiraju ispitanici koji se informišu o odevnom predmetu koji ih interesuje oflajn i kupuju isti u fizičkim prodavnicama (30\% ispitanika). Međutim, $10,8 \%$ ispitanika je označilo da preferira informisanje i kupovinu odeće onlajn, dok je najmanji broj ispitanika koji se informišu oflajn, a kupuju onlajn (3,3\%). Može se zaključiti da najveći broj ispitanika preferira kupovinu odeće oflajn, a da su ispitanici podeljeni po pitanju izbora izvora informisanja, gde više od polovine preferira istraživanje i poređenje proizvoda onlajn (Grafikon 1).
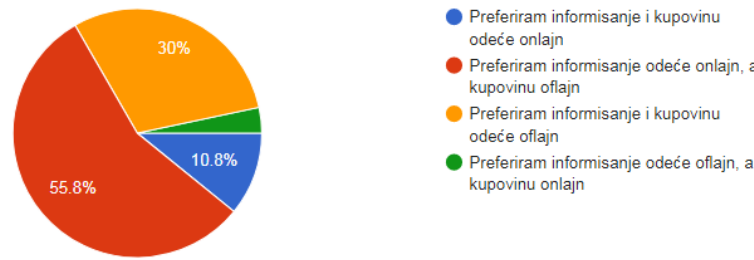

Grafikon 1: Da li preferirate informisanje o kupovini $i$ kupovinu odeće u fizičkim prodavnicama ili onlajn?

Većina ispitanika je do sada kupovala onlajn odeću, ali postoje problemi vezani za nedovoljnu informisanost velikog broja ispitanika o onlajn trgovini, uslovima i pogodnostima koje ona nudi. To bi se trebalo promeniti jer nedovoljna informisanost svakako može biti razlog za davanje prioriteta oflajn kupovini.Najveći rizik prilikom onlajn kupovine za potrošače predstavlja rizik obećanog i isporučenog, kao i nemogućnst povrata robe. S druge strane, dominiraju ispitanici koji nisu bili prevareni prilikom onlajn kupovine što se odnosi na kreiranje pozitivnih iskustava o istoj, pozitivno deljenje mišljenja i preporuka, kao i na moguće ponovljene kupovine.

Ispitanici uglavnom kupuju odeću u fizičkim prodavnicama sa porodicom/prijateljima, odnosno svojim najbližima, pa samim tim oni mogu u velikoj meri da utiču, kako na izbor prodavnice u kojoj će se obaviti kupovina, tako i na izbor garderobe. Kompanije se trebaju truditi da u što većoj meri udovolje potrošačima jer se tako ostvaruje lojalnost na dug rok, kao i pridobijanje novih kupaca putem širenja pozitivnih informacija o istoj.

Kada je u pitanju izbor onlajn prodavnice, ispitanici uglavnom preferiraju kupovinu odeće preko zvaničnih sajtova neke kompanije i kupovinu odeće preko društvenih mreža. To su najpopularnije onlajn prodavnice, a pored njih, ispitanici naručuju i preko sajtova kao što su AliExpress, eBay, Amazon i drugi. Što se tiče oflajn prodavnica, većina ispitanika preferira kupovinu $\mathrm{u}$ prodavnicama globalnih brendova, zatim prodavnicama domaćih proizvođača. Pored tih prodavnica, određeni broj ispitanika kupuje odeću u prodavnicama polovne garderobe. Izbor onlajn/oflajn prodavnice pokazuje sklonosti potrošača ka određenim markama odeće, odnosno brendu kompanije.

Po pitanju kriterijuma koji su značajni prilikom izbora onlajn i oflajn prodavnice, može se zaključiti da je zajedničko za obe prodavnice davanje prioriteta kvalitetu i ceni prilikom izbora odeće. Kod onlajn prodavnice, pored kvaliteta i cene, dominiraju recenzije proizvoda i poštarina. Nakon njih, prednost se daje izgledu i preglednosti veb sajta/stranice, preporukama prijatelja, popustima/sniženjima i načinu plaćanja. Kada su u pitanju oflajn prodavnice, nakon cene i kvaliteta, prioritet se daje izgledu i preglednosti prodajnog objekta i popustima/ sniženjima. Pored navedenih kriterijuma, ljubazno osoblje i preporuke prijatelja zauzimaju značajno mesto pri izboru oflajn prodavnice.

Kao najčešće razloge kupovine preko interneta polovina ispitanika je izdvojila uštedu vremena, dostavu proizvoda na adresu, veći izbor proizvoda i nepostojanje gužve prikom onlajn kupovine. Oko $28 \%$ ispitanika je izdvojilo preglednost proizvoda onlajn u odnosu na oflajn kupovinu kao razlog donošenja odluke o onlajn kupovini, dok je oko $26 \%$ ispitanika označilo poređenje proizvoda iz kućnih pogodnosti kao razlog onlajn kupovine proizvoda. Najmanji broj ispitanika je označio nepostojanje vremenskih ograničenja kao razlog kupovine onlajn $(16,7 \%)$. Može se zaključiti da potrošačima odgovaraju pogodnosti koje onlajn kupovina pruža, gde prednost daju vremenu, dostavi proizvoda i nepostojanju gužve u onlajn prodavnici (Grafikon 2).

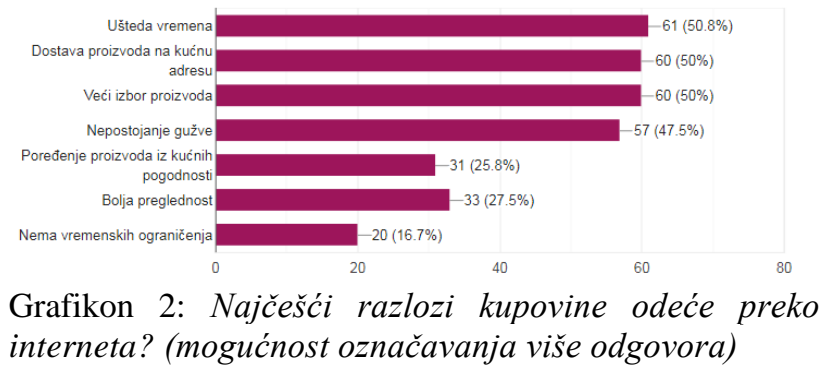

$\mathrm{Na}$ osnovu rezultata istraživanja, može se zaključiti da kao najčešći razlog oflajn kupovine dominira mogućnost isprobavanja robe $(89,2 \%)$, što kod onlajn kupovine nije moguće. Preko polovine ispitanika je označilo sigurnost i poverenje, kao i posedovanje proizvoda odmah nakon plaćanja kao bitne razloge za opredelivanje za oflajn kupovinu. Nešto manji broj ispitanika je označio neposredan kontakt sa prodavcem $(14,2 \%)$, kao i osećaj ispunjenosti $(21,7 \%)$ kao razloge kupovine u fizičkoj prodavnici.

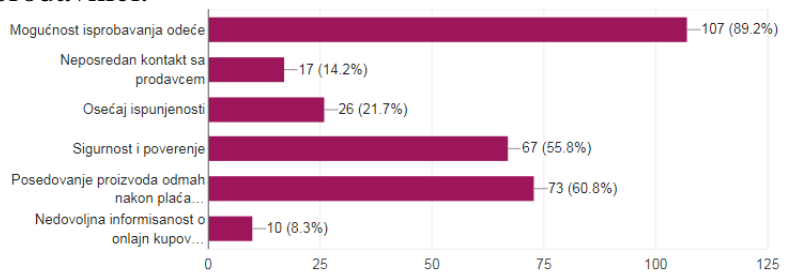

Grafikon 3: Najčešći razlozi kupovine odeće u fizičkim prodavnicama? (mogućnost označavanja više odgovora) 
Poslednja dva pitanja su kontrolna pitanja, gde su ispitanici na skali od 1 do 5 trebali da označe koliko zaista preferiraju oflajn, odnosno onlajn kupovinu.

$\mathrm{Na}$ grafikonu 4 prikazano je slaganje sa datom izjavom. Gotovo svi ispitanici su pozitivno odgovorili, čak se preko $50 \%$ ispitanika u potpunosti slaže sa navedenom tvrdnjom. Može se zaključiti da ispitanici ipak više pažnje posvećuju oflajn trgovini, gde im sigurnost, pouzdanost, mogućnost isprobavanja i osećaj ispunjenosti predstavljaju najbitnije stavke pri kupovini odeće. Iako se onlajn trgovina u velikoj meri razvija i postaje sve popularnija, veliki broj potrošača i dalje daje prednost tradicionalnoj trgovini.

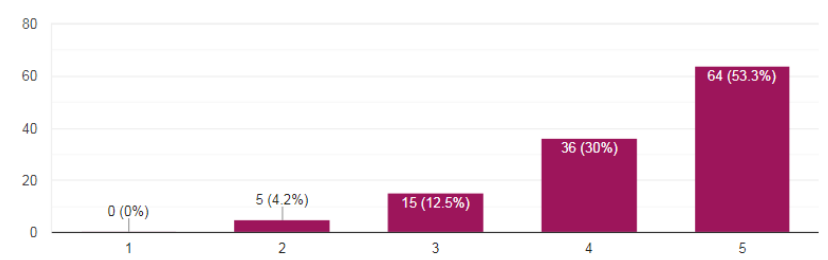

Grafikon 4: Preferiram oflajn kupovinu u fizičkoj prodavnici. (1-uopšte se ne slažem; 5 - u potpunosti se slažem)

Kada je u pitanju onlajn kupovina, tvrdnja čiji su odgovori prikazani na grafikonu 5 analizira celokupan stav potrošača prema onlajn kupovini. Ispitanici su imali podeljenja mišljenja po pitanju preferiranja onlajn kupovine. Dominiraju ispitanici koji se osrednje $(26,7 \%)$ ili u maloj meri $(26,7 \%)$ slažu sa navedenom tvrdnjom. Manji broj ispitanika se veoma ili u potpunosti slaže sa tim da preferiraju onlajn kupovinu. Na osnovu toga, može se zaključiti da većina ispitanika ipak preferira oflajn kupovinu.

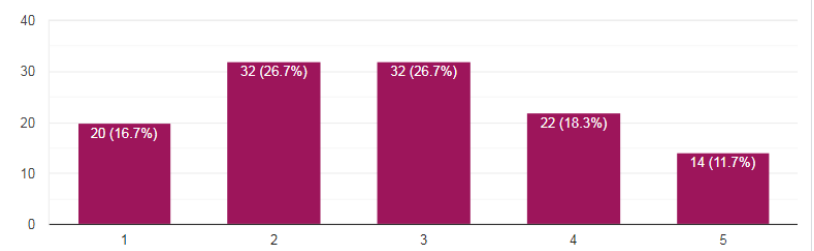

Grafikon 5: Preferiram onlajn kupovinu preko interneta. (1-uopšte se ne slažem; 5 - u potpunosti se slažem)

Generalno gledano, oflajn kupovina $u$ fizičkim prodavnicama i dalje zauzima bitnije mesto gde će potrošači obaviti kupovinu odeće. $\mathrm{Na}$ osnovu dobijenih odgovora, može se zaključiti da onlajn kupovina za većinu potrošača predstavlja rizik, potrošači nisu dovoljno informisani i nemaju dovoljno poverenja u dobijanje stvarnog proizvoda u odnosu na očekivani.

\section{ZAKLJUČAK}

Prilikom odlučivanja o kupovini različitih proizvoda potrošači ulažu različite napore. U kupovini prehrambenih proizvoda potrošači ulažu najmanje napora, pa se odluka o kupovini ovih proizvoda donosi rutinski i bez velikog razmišljanja.Sa druge strane, kod kupovine šoping proizvoda, npr. odeće, potrošači ulažu dosta vremena i uzimaju u obzir razne kriterijume pri donošenju odluke, kao što su cena, kvalitet, prodajni objekat, ljubaznost osoblja, poštarina, i sl. Samom činu kupovine prethodi duže razmišljanje i razmatranje raznih opcija i na kraju donošenje konačne odluke o kupovini.

Potrošači se često dvoume o kupovini u onlajn ili oflajn prodavnicama kada su u pitanju šoping proizvodi. I jedna i druga kupovina imaju svoje prednosti i nedostatke, a stavovi i navike potrošača su presudni prilikom odabira prodavnice u kojoj će se obaviti kupovina. Pogodnosti koje pruža onlajn kupovina su ušteda vremena, poređenje proizvoda iz kućnih pogodnosti, nepostojanje gužve, veći izbor proizvoda, dostupnost 24 sata dnevno, dostava proizvoda na kućnu adresu i sl. S druge strane, pogodnosti koje pruža oflajn trgovina su mogućnost isprobavanja proizvoda, sigurnost i poverenje, posedovanje proizvoda odmah nakon plaćanja, neposredan kontakt sa prodavcem, osećaj ispunjenosti i sl.

Kupovina je zadovoljstvo, bez obzira da li potrošači vole da lutaju ulicama tražeći određeni proizvod koji žele da kupe ili ako lutaju po više veb stranica ili profila na društvenim mrežama pokušavajući da pronađu proizvod koji bi zadovoljio njihovu potrebu ili želju.

Samo one organizacije koje uspevaju da kreiraju i isporuče pravu vrednost za potrošače, imaju zagarantovani uspeh na tržištu, ostvarenje poslovnih ciljeva i sigurne i lojalne potrošače. Danas potrošač ne očekuje od preduzeća samo da zadovolji njegove potrebe, već i da njegova očekivanja prerastu u oduševljenje. Zadovoljan kupac koji svoje zadovoljstvo deli sa prijateljima i poznanicima je najbolji promoter proizvoda.

\section{LITERATURA}

[1]M. Gašović, "Menadžment proizvoda”, Subotica, Ekonomski fakultet, 2011.

[2]S. Salai, A. Grubor, "Marketing komunikacije", Subotica, Ekonomski fakultet, 2011

[3]Žnideršić, R. Kovač, D. Marić, "Društvene determinante ponašanja potrošača”, Subotica, Ekonomski fakultet, 2007.

[4]V. Vulić, "Društveni mediji kao inovativni oblik neplaćenih medija”, Podgorica, Ekonomski fakultet 2011

[5] S. Quinton, L. Simkin, "The digital journey: Reflected Learnings and Emerging Challengs", 2016.

[6] P. Kotler, K. Keller, "Marketing Management", New Jersey, Pewntice Hall, 2012.

[7] G. Sonja, A. Ewald, Empirical research in on-line trust: a review and critical assessment. International Journal of Human-Computer Studies, 586, 783-812, 2003.

[8]https://manager.ba/kolumne/online-vs-offline-prodajnikanali (pristupljeno u oktobru 2020.)

[9] https://services.amazon.in/resources/seller-blog/onlineshopper-vs-offline-shopper.html

(pristupljeno u oktobru 2020.)

\section{Kratka biografija:}

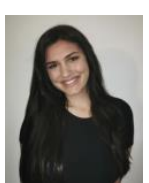

Kristina Lugonja rođena je u Trebinju 1996. god. Završila Ekonomski fakultet u Novom Sadu. Upisala je Master akademske studije na Fakultetu tehničkih nauka 2019. godine iz oblasti Industrijsko inženjerstvo i menadžment. 